\title{
Evaluation of Arbuscular Mycorrhizal Fungal Formulations on Yield and Tuber Characteristics of Potato (Solanum tuberosum L.) cv. Kufri Sindhuri
}

\author{
Trivikram, B.K. Singh, Ajay Kumar Tiwari*, Pankaj Kumar Singh and A.K. Singh \\ Department of Horticulture, Institute of Agricultural Sciences, B.H.U, \\ Varanasi-221005 (UP) India \\ *Corresponding author
}

Keywords

Mycorrhizae, Solanum tuberosum L., Tuber, Yield

Article Info

Accepted:

18 July 2020

Available Online:

10 August 2020

\section{A B S T R A C T}

Arbuscular mycorrhizal fungal symbiosis has a significant impact on sustainable growth and development of various plants as they help to acclimatize with biotic and abiotic conditions. A study was conducted to determine the effects of various mycorrhizae based products at different concentrations on yield and quality of potato (Solanum tuberosum L.) cv. Kufri Sindhuri during Rabi 2016-17 at Vegetable research farm, Department of Horticulture, Institute of Agricultural Sciences, BHU, Varanasi. The experiment consists of 8 treatments involving different mycorrhizal products and untreated (control). Observation on all the characters was made on five random plants of individual plots and in each treatment and replication. The observation recorded on the five plants was averaged to get mean value. From the result, treatment $\mathrm{T}_{2^{-}}$soil application with Myc100@250g/ha showed very promising result for almost all the characters under investigation viz., number of tubers per plant (11.62), tuber length (6.19 $\mathrm{cm})$, tuber width $(4.69 \mathrm{~cm})$, tuber yield per plot $(33.7 \mathrm{~kg})$, tuber yield $(\mathrm{kg} / \mathrm{ha})$ (32063.73), marketable tuber yield/plot (30.44 kg) as compared to other treatments. This was followed by $\mathrm{T}_{8^{-}}$soil application with Bolt Gr. @ 10kg/ha. At much higher concentration, the mycorrhizal products imposed adverse effects on growth and yield attributes. It can be concluded that mycorrhiza can be used as a remarkable supplement for increasing growth and yield of potato along with commonly used fertilizers.

\section{Introduction}

Mycorrhizae are known to carry out many functions such as improvement of plant establishment, growth enhancement, and plant protection against biotic and abiotic stresses
(Smith and Read, 1997). There is a mutual association between the mycorrhizae and the plants. The fungus has relatively constant and direct access to mono or dimeric carbohydrates, such as glucose and sucrose produced by the plant during photosynthesis. 
This get translocated from the source location (usually leaves) to the root tissues and then to the fungal partners. In return, the plants through the mycelium's very large surface area are able to absorb water and mineral nutrients from soil. This improves the mineral absorption capability of the plant roots (Harrison, 2005). Mycorrhizae release enzymes in the soil which dissolve uneasily available soil micronutrients, such as organic nitrogen, phosphorus and iron. Arbuscular mycorrhizal fungi are widespread and agronomically important plant symbiont and often stimulate plant uptake of nutrients such as Phosphorus, Zinc, Copper, and Iron in deficient soil (Liu et al., 2002).

Undisturbed soils are full of mycorrhizae along with other micro-organism. However, research has shown that many common practices such as tillage, fumigation, removal of top soil, and soil compaction, reduce mycorrhizal forming potential of soil. Mycorrhizae populations are slow to recolonize unless there is close access to natural resources that can act as the source of mycorrhizal spores. Introducing the mycorrhizal spores in nutrient and water deficient areas greatly improves the nutrient and water absorption which improves plant growth. With the beneficial effects of mycorrhiza, there is need to promote mycorrhizal symbiosis naturally with plants. Adopting minimum tillage, optimum use of fertilizers, crop rotations, less use of pesticides, breeding of crops which are naturally responsive to mycorrhizal population are measures to improve mycorrhizal population naturally.

Potato (Solanum tuberosum L.) is considered as a major tuber vegetable crop in many parts of the world and is mostly grown under tropical/subtropical and temperate region of India. Arbuscular mycorrhizal hyphae extend into soil beyond the nutrient zone and thus, can increase the effectiveness of absorption of immobile elements. AM fungi also improves soil aggregation and water-holding capacity both by producing hyphae external to the host plant root tissues and by exuding glomalin, a glycoprotein, from extra radical hyphae (Sharma et al., 2017). Horticultural crops and flowers have been used as potential target plants for practical use of mycorrhizal inoculation (Chang, 1994, Lovato et al., 1995, Srámek et al., 2000). The method of application of mycorrhiza in growing plant is by adding mycorrhizal fungi inoculum to the planting hole at the time of transplanting which requires large amounts of inoculum. The best option is to use for nursery seedlings grown in trays. Inoculation with AM fungi at very early stages (seed sowing) has been found to result in higher crop uniformity, reduced transplant mortality and higher yields after transplanting to the field This experiment was conducted to study the effects of various mycorrhizae based products on yield and tuber characteristics of potato (Solanum tuberosum L.) cv. KufriSindhuri.

\section{Materials and Methods}

The study was carried out once during Rabi season 2016-17 at Vegetable Research Farm of Department of Horticulture, Institute of Agricultural sciences, B.H.U., Varanasi (U.P.).The Experiment was laid out in a Randomized Complete Block Design (RCBD) with 3 replications. The plant spacing was 60 $\mathrm{cm}$ between rows and $15 \mathrm{~cm}$ within rows. Experiment consisted of two applications of eight treatments which comprises of different products of mycorrhizae, at different concentrations. The application was done at 20 and 50 days after planting. The cultivar used in the experiment was kufri sindhuri. The mycorrhizal products included in the study are $\mathrm{T}_{1}$ - Control (without mycorrhiza), $\mathrm{T}_{2^{-}}$soil application with myc100@250 g/ha, $\mathrm{T}_{3^{-}}$soil application with myc100@500 g/ha, 
$\mathrm{T}_{4^{-}}$soil application with Rhizo Myco100 $@ 250 \mathrm{~g} / \mathrm{ha}, \quad \mathrm{T}_{5^{-}}$soil application with RhizoMyco100 @500g/ha, $\mathrm{T}_{6^{-}}$soil application with RhizoMyxo100 @ 250g/ha, $\mathrm{T}_{7}$ - soil application with RhizoMyxo100 @ 500g/ha, T8- soil application with Bolt Gr. @ $10 \mathrm{~kg} / \mathrm{ha}$. The first spray of mycorrhizal product were performed 20 days after sowing on $4^{\text {th }}$ December, 2015 and second spray done 50 days after sowing on $3^{\text {th }}$ January, 2016. Battery operated sprayer was use for spraying. Spray was targeted towards the roots of plants. Both the spray was done in all the plots except control. A total of seven parameter including numbers of tubers per plant, weight of tuber/plant $(\mathrm{g})$, length of tuber $(\mathrm{cm})$, width of tuber $(\mathrm{cm})$, tuber yield/plot (kg), tuber yield/ ( $\mathrm{kg} / \mathrm{ha})$, and marketable tuber yield $(\mathrm{kg} / \mathrm{ha})$ were studied. The observation recorded on the five plants was averaged to get mean value, and the data was subjected to statistical analysis. For statistical analysis, mean of different treatments were analyzed by the method outlined by Cochran and Cox

\section{Results and Discussion}

\section{Number of tubers/plant}

Increased phosphorus content in plant leads to significant increase in the number of tubers per plant. It exerted a positive effect on cell division and energy storage and also an increase uptake of nutrients by the plant roots facilitates sprouting of more eye buds of the tubers. Highest number of tubers/plant (11.62) was recorded in treatment $T_{2}$ - soil drench with myco100@250 g/ha followed by $\mathrm{T}_{8^{-}}$ soil application with Bolt Gr. @ 10 kg/ha had 11.36 no. of tuber/plant, while minimum number of tubers/plant (7.84) was observed in treatment $T_{1}$ - untreated control. These results were in agreement with the earlier findings of Manjarrez-Martinez et al., (1999) on chilli; Yao et al., (2002); Ryan et al., (2000); El-
Haddad and Awad (2007); Hadad et al., (2012) on tomato; Castillo et al., (2013) on Chilean pepper; Gurumurthy et al., (2014) on chilli and Buysens et al., (2016).

\section{Weight of tuber/plant (g)}

Increase in weight of tubers due to greater accumulation of photosynthates as well as carbohydrates in the tubers. The maximum tuber weight was noticed in the treatment $\mathrm{T}_{4}$ soil application with RhizoMyco 100 @ $250 \mathrm{~g} / \mathrm{ha}(843.71 \mathrm{~g})$ followed by $\mathrm{T}_{6}$ - soil application with RhizoMyxo 100 @250 g/ha $(818.67 \mathrm{~g})$, while the lowest weight of tuber/plant $(510.78 \mathrm{~g})$ was noticed in treatment $\mathrm{T}_{1}$ - untreated control. These results are in line with the finding of El-Haddad and Awad (2007); Hadad et al., (2012) on tomato; Castillo et al., (2013) on chilean pepper; Alawathugoda (2014) and Buysens et al., (2016) on tomato.

\section{Length of tuber (cm)}

Different mycorrhizal inoculation increased the tuber length significantly. Maximum tuber length $(6.19 \mathrm{~cm})$ registered in treatment $\mathrm{T}_{2^{-}}$ soil drenchwith@myco100@250 g/ha, followed by $\mathrm{T}_{4}$-soil application with RhizoMyco 100 @ 250g/ha (6.10cm),whereas the minimum length of tuber $(5.11 \mathrm{~cm})$ was recorded in treatment $\mathrm{T}_{1^{-}}$untreated control. The results obtained were in conformity with the previous finding of Ghosh and Das (1998); Castillo et al., (2013) on Chilean pepper; Ekin et al., (2013) and Buysens et al., (2016) on potato.

\section{Width of tuber $(\mathrm{cm})$}

Width of tuber increased significantly with highest tuber width $(4.69 \mathrm{~cm})$ recorded in treatment $\mathrm{T}_{2}$ - soil drench with myco100 @ $250 \mathrm{~g} / \mathrm{ha}$ followed by $\mathrm{T}_{4}$ soil application with RhizoMyco 100 @ 250g/ha $(4.24 \mathrm{~cm})$. 
Minimum width of tuber $(3.14 \mathrm{~cm})$ was recorded in treatment $T_{1}$ - untreated control. The results obtained were in accordance with the finding of Ghosh and Das (1998); Banu et al., (2013) on tomato; Ekin et al., (2013) and Buysens et al., (2016) on potato.

\section{Tuber yield/plot (kg)}

The treatment of arbuscular mycorrhizal product increased the production significantly. Significant differences were observed in tuber yield per plot. The maximum tuber yield per plot $(33.7 \mathrm{~kg})$ was recorded in treatment $\mathrm{T}_{2}$ - soil drench with myco100@250 g/ha, while minimum tuber yield was recorded in treatment $\mathrm{T}_{1}$ - untreated control $(27.20 \mathrm{~kg})$. These results were in conformity with the earlier work of Ghosh and Das (1998); Ryan et al., (2000); ElHaddad and Awad (2007); Gaurav et al., (2010); Ekin et al., (2013) and Buysens et al., (2016) (Table 1).

Table.1 Effect of various mychorrhizal products on yield and tuber characteristics of potato

\begin{tabular}{|c|c|c|c|c|c|c|c|}
\hline Treatments & $\begin{array}{l}\text { Number of } \\
\text { tubers/plant }\end{array}$ & $\begin{array}{c}\text { Weight of } \\
\text { tuber/plant } \\
\text { (g) }\end{array}$ & $\begin{array}{l}\text { Length } \\
\text { of tuber } \\
\text { (cm) }\end{array}$ & $\begin{array}{l}\text { Width } \\
\text { of tuber } \\
\text { (cm) }\end{array}$ & $\begin{array}{c}\text { Tubers } \\
\text { yield/plot } \\
\text { (kg) }\end{array}$ & $\begin{array}{l}\text { Tuber } \\
\text { yield } \\
\text { (kg/ha) }\end{array}$ & $\begin{array}{c}\text { Marketable } \\
\text { tubers yield } \\
\text { (kg/ha) }\end{array}$ \\
\hline $\mathbf{T}_{1}$ Control & 7.84 & 510.78 & 5.11 & 3.14 & 29.15 & 29063.73 & 18092.00 \\
\hline $\begin{array}{c}T_{2} \text { Myco100 @ } \\
250 \mathrm{~g} / \mathrm{ha}\end{array}$ & 11.62 & 803.46 & 6.19 & 4.69 & 33.09 & 33541.63 & 21508.00 \\
\hline $\begin{array}{c}\text { T3 Myco100@ } \\
\text { 500g/ha }\end{array}$ & 10.36 & 732.52 & 5.63 & 4.53 & 31.38 & 31705.70 & 19506.67 \\
\hline $\begin{array}{c}\text { T4 } \\
\text { RhizoMyco100 } \\
\text { @ 250g/ha }\end{array}$ & 10.96 & 843.71 & 6.10 & 4.20 & 31.84 & 30468.70 & 18480.00 \\
\hline $\begin{array}{c}\text { T5RhizoMyco100 } \\
\text { @ 500g/ha }\end{array}$ & 9.54 & 659.99 & 5.75 & 4.51 & 30.93 & 29166.12 & 21188.33 \\
\hline $\begin{array}{c}\text { T6 } \\
\text { RhizoMyxo100@ } \\
\text { 250g/ha }\end{array}$ & 10.74 & 818.67 & 5.87 & 4.45 & 31.63 & 31712.73 & 20289.00 \\
\hline $\begin{array}{c}\text { T7 } \\
\text { RhizoMyxo100 } \\
\text { @ 500g/ha }\end{array}$ & 8.93 & 619.36 & 5.44 & 4.16 & 30.29 & 30168.32 & 18998.33 \\
\hline $\begin{array}{c}\text { T8 Bolt Gr. @ } \\
\text { 10kg/ha }\end{array}$ & 11.36 & 800.93 & 5.84 & 4.57 & 32.12 & 32063.73 & 21684.00 \\
\hline $\mathrm{SE}(\mathrm{d})$ & 0.37 & 10.82 & 0.205571 & 0.15486 & 1.0 & 1668.086 & 1332.359 \\
\hline CD at $5 \%$ & 0.80 & 23.21 & 0.424277 & 0.319614 & 2.5 & 3577.688 & 2749.854 \\
\hline
\end{tabular}

\section{Tuber yield (kg/ha)}

The maximum tuber yield $(\mathrm{kg} / \mathrm{ha})$ was recorded in the treatment $T_{2}$ - soil drench with myco100 @ $250 \mathrm{~g} / \mathrm{ha}(33541.67 \mathrm{~kg} / \mathrm{ha})$ followed by $\mathrm{T}_{8^{-}}$soil application with Bolt Gr. @ $10 \mathrm{~kg} / \mathrm{ha} \quad(32063.73 \mathrm{~kg} / \mathrm{ha}$.), while minimum tuber yield $(\mathrm{kg} / \mathrm{ha})$ was recorded in treatment $\mathrm{T}_{1}$ - untreated control (29063.73 $\mathrm{kg} / \mathrm{ha}$ ). The significant increase in tuber yield 
per hectare was due to better nutrient absorption of plant which resulted in better vegetative growth and increased plant biomass. These results were in conformity with the earlier work of Ghosh and Das (1998); Ryan et al., (2000).

\section{Marketable tuber yield/Plot (kg)}

Highest marketable tuber yield/plot was recorded in treatment $T_{2}$ - soil drench with myco100 @ 250 g/ha (30.44 kg), followed by

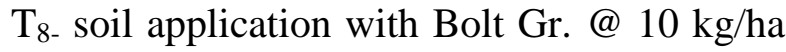
(29.67 kg.). Whereas, minimum marketable tuber yield/plot (25.81) was observed in Treatment $\mathrm{T}_{1}$-untreated control. The significant increase in marketable tuber yield per hectare was due to better nutrient absorption of plant which resulted in better vegetative growth and increased plant biomass. These results were in conformity with the earlier work of Ghosh and Das (1998); Ryan et al., (2000); El-Haddad and Awad (2007); Gaurav et al., (2010); Ekin et al., (2013) and Buysens et al., (2016).

All the treated plots performed better than the untreated plot because, drenching of the mycorrhizal formulations in the root zone might have resulted in colonization leading to an increase in nutrient absorption, plant growth, early flowering, better root growth and higher yield. The results thus revealed that all the mycorrhiza-based products have shown significant potential for enhanced yield performance over the untreated treatment. This stressed the importance of symbiotic organisms in crop growth.

Hence concluded thus the results reveal that all the mycorrhiza-based products have shown significant potential for good vegetative growth and enhanced yield performance over the untreated treatment thus stressing the importance of symbiotic organisms in crop growth and resistance towards the stresses.
This stressed the importance of symbiotic organisms in crop growth. The present study indicated that treatment $\mathrm{T}_{2^{-}}$soil application with Myc100@ 250g/ha is the best mycorrhizal application to enhance growth and yield in potato.

\section{References}

Alawathugoda, C. J. and Nilanthi, D. 2014. Effects of mycorrhiza as a substitute for inorganic fertilizer on growth and yield of Tomato (Lycopersicon esculentum L.) and Soybean (Glycine $\max$ L.), and soil microbial activity. Tropical Agricultural Research and Extension. 16(4): 107-112.

Banu, M. B., Bhuiyan, M. A. H. and Alam, F. 2013. Effect of arbuscular mycorrhizal fungi and phosphorus on tomato. International Journal of Sustainable Agricultural Technology. 9(11): 5-11.

Buysens, C., Cesar, V., Ferrais, F., Boulois, H. D. and de Declerck, S. 2016. Inoculation of Medicago sativa cover crop with Rhizophagus irregularis and Trichoderma harzianum increases the yield of subsequently-grown potato under low nutrient conditions. Applied Soil Ecology. 105: 137-143.

Castillo, C., Morales, A., Rubio, R.,Barea, J. M. and Borie, F. 2013. Interactions between native arbuscular mycorrhizal fungi and phosphate solubilizing fungi and their effect to improve plant development and fruit production by Capsicum annuum L. African Journal of Microbiology Research. 7(26): 3331-3340.

Chang, D. C. 1994. What is the potential for management of vesicular arbuscular mycorrhizae in horticulture? Developments in Plant and Soil Sciences. 56: 187-190.

Cochran WG, Cox GM. 1957. Experimental designs. John Wiley and Sons Inc., 
New York; pp. 611.

Ekin, Z., Demir, S., Oguz, F. and Yildirim, B. 2013. Effect of Arbuscular Mycorrhizal Fungus (AMF) Glomus intraradices with different potassium fertilizer levels on the tuber yield and size distribution of potato (Solanum tuberosum L.). Journal of Agricultural Sciences. 23(2): 154-163.

El-Haddad, S. A. and Awad, E. M. M. 2007. Influence of vesicular arbuscular mycorrhizae, NK fertilization rates and foliar application of micronutrients on growth, yield and quality of potatoes. Arab Universities Journal of Agricultural Sciences. 15(2): 441-454.

Gaurav, S.S., Sirohi, S. P. S., Singh, B.and Sirohi P. 2010. Effect of mycorrhiza on growth, yield and tuber deformity in potato (Solanum tuberosum L.) grown under water stress conditions. Progressive Agriculture. 10(1):35-41.

Ghosh, D. C. and Das, A. K. 1998. Effect of biofertilizers and growth regulators on growth and productivity of potato (Solanum tuberosum L.). Indian Agriculturist. 42(2):109-113.

Gurumurthy, S. B., Patil, S. V., Vidyavathi, K. B., Lokesh, M. S., Shankrappa, T. H. and Bellakki, M. A. 2014. Agricultural Performance of local isolates of arbuscular mycorrhizal (AM) fungi on growth and yield of chilli (Capsicum annuum L.) grown in black clayey soil. International Journal of Current Microbiology and Applied Sciences. 3(9): 404-408.

Hadad, M. A., Al-Hashmi, H. S. and Mirghani, S. M. 2012. Tomato (Lycopersicon esculentum Mill.) growth in response to salinity and inoculation with native and introduced strains of mycorrhizal fungi. International Research Journal of Agricultural Science and Soil Science.
2(6): 228-233.

Harrison, MJ. 2005. Signaling in the arbuscular mycorrhizal symbiosis. Annual Review of Microbiology. 59: $19-42$.

Liu, A., Hamel, C., Elmi, A., Costa, C., Ma, B. and Smith, D. L. 2002 Concentrations of $\mathrm{K}, \mathrm{Ca}$ and $\mathrm{Mg}$ in maize colonized by arbuscular mycorrhizal fungi under field conditions. Canadian Journal of Soil Science. 82(3): 272-278.

Lovato, P. E., Schüepp, H., Trouvelot, A., \& Gianinazzi, S. 1995. Application of arbuscular mycorrhizal fungi (AMF) in orchard and ornamental plants. In Mycorrhiza (pp. 443-467). Springer, Berlin, Heidelberg: 521-559.

Manjarrez-Martinez, M. J., Ferrera-Cerrato, R. and Gonzalez-Chavez, M. C. 1999. Effect of vermicompost and mycorrhizal fungi on growth and photosynthetic rate of chilli. Terra. 17(1): 9-15.

Ryan, N. A., Deliopoulos, T., Jones, P. and Haydock, P. P. J. 2000. Effects of mycorrhizal fungi on the potato potato cyst nematode interaction. Aspects of Applied Biology. 12(59): 131-140.

Smith, S.E. and Read D.J. 1997. Mycorrhizal Symbiosis. London, 2nd ed. Academic Press.16th IFOAM Organic World Congress, Modena, Italy, June 16-20, 2008 Archived at http://orgprints.org/view/projects/conf erence.html.

Šrámek, F., Dubský, M., and Vosatka, M. 2000. Effect of arbuscular mycorrhizal fungi and Trichoderma harzianum on three species of balcony plants. Rostlinná Výroba. 46(3): 127-131.

Suvigya Sharma, Ram Prasad, Ajit Varma and Anil Kumar Sharma. 2017. Glycoprotein Associated with Funneliformis coronatum, Gigaspora 
margarita and Acaulospora scrobiculata Suppress the Plant Pathogens In vitro. Asian Journal of Plant Pathology. 11: 199-202.

Yao, M. K., Tweddell, R. J. and Desilets, H. 2002. Effect of two vesicular- arbuscular mycorrhizal fungi on the growth of micro-propagated potato plantlets and on the extent of disease caused by Rhizoctonia solani. Mycorrhiza. 12(5): 235-242.

\section{How to cite this article:}

Trivikram, B.K. Singh, Ajay Kumar Tiwari, Pankaj Kumar Singh and Singh, A.K. 2020. Evaluation of Arbuscular Mycorrhizal Fungal Formulations on Yield and Tuber Characteristics of Potato (Solanum tuberosum L.) cv. Kufri Sindhuri. Int.J.Curr.Microbiol.App.Sci. 9(08): 1943-1949. doi: https://doi.org/10.20546/ijcmas.2020.908.222 